\title{
O IMPACTO DA LEI DE RESPONSABILIDADE FISCAL SOBRE A GESTÃO FINANCEIRA MUNICIPAL: um estudo com os municípios do Paraná
}

\section{1- Willson Gerigk*}

Mestrado em Contabilidade pela Universidade Federal do Paraná (UFPR)

Professor do curso de graduação em Ciências Contábeis, Campus de Irati da Universidade Estadual do Centro-Oeste (UNICENTRO).

gerigkw@yahoo.com.br

http://lattes.cnpq.br/9085562155938774

\section{2- Ademir Clemente}

Doutorado em Engenharia de Transportes pela Universidade Federal do Rio de Janeiro (UFRJ) Professor do Mestrado em Contabilidade da Universidade Federal do Paraná (UFPR). ademir@ufpr.br

http://lattes.cnpq.br/3021828547126069

\section{3- Marinês Taffarel}

Doutoranda em Administração pela Pontifícia Universidade Católica do Paraná (PUC-PR)

Professora do curso de graduação em Ciências Contábeis, Campus de Irati da Universidade Estadual do Centro-Oeste (UNICENTRO).

marinestaffarel@yahoo.com.br

http://lattes.cnpq.br/3545046580485799 


\title{
O IMPACTO DA LEI DE RESPONSABILIDADE FISCAL SOBRE A GESTÃO FINANCEIRA MUNICIPAL: UM ESTUDO COM OS MUNICÍPIOS DO PARANÁ
}

\section{RESUMO}

Este artigo tem por objetivo mensurar e avaliar os reflexos da Lei de Responsabilidade Fiscal (LRF) sobre o espaço de manobra da gestão financeira dos municípios paranaenses extremamente pequenos e dos pequenos. A pesquisa é caracterizada como descritiva e explicativa quanto aos objetivos; bibliográfica e documental quanto aos procedimentos; e quantitativa quanto à abordagem do problema. O universo da pesquisa são os municípios paranaenses com população menores que 5 mil habitantes e os com população entre 10 e 20 mil habitantes; a amostra e composta pelos municípios que disponibilizaram informações junto à base de dados Finanças do Brasil -FINBRA/STN. A técnica estatística empregada é a regressão linear múltipla. Nas análises de regressão foram usadas 22 variáveis explicativas, envolvendo aspectos financeiros e de gestão dos municípios. Conclui-se que o espaço de manobra da gestão financeira tanto nos municípios paranaenses extremamente pequenos como nos pequenos, não foi reduzido pela LRF, como era esperado; e que os aspectos que mais contribuem para com o espaço de manobra municipal, nos municípios extremamente pequenos estão associados aos gastos com pessoal, e nos pequenos dizem respeito à diferença entre as receitas e as despesas correntes.

\section{Palavras-chave}

Finanças públicas. Gestão financeira municipal. Administração municipal.

\section{THE IMPACT LAW OF FISCAL RESPONSIBILITY OF THE FINANCIAL MANAGEMENT MUNICIPAL: A STUDY OF MUNICIPALITIES OF PARANÁ STATE}

\begin{abstract}
This article seeks to quantify and assess the repercussions of the Law of Fiscal Responsibility (LRF) on the operating space of the financial management of municipalities of Paraná extremely small and small. The research is characterized as descriptive and explanatory as to the objectives, literature and documents about the procedures, and on the quantitative approach to the problem. The research is the municipal districts with population less than 5000 inhabitants and those with population between 10 and 20000 inhabitants, and the sample consists of the municipalities which have provided information to the database Finance of Brazil - FINBRA/STN. The statistical technique used is multiple linear regression. In the regression analysis were used 22 explanatory variables, including aspects and financial management of municipalities. We conclude that the leeway for financial management in both the extremely small municipalities of Paraná and in the small, was not reduced by the LRF, as expected, and that the aspects that contribute most to the leeway with municipal municipalities in extremely small are related to personnel expenses, and small refer to the difference between revenue and current expenditure.
\end{abstract}

\section{Keywords}

Public finances. Municipal financial management. Municipal administration. 


\section{INTRODUÇÃO}

A organização político-administrativa brasileira, definida na Constituição Federal de 1988, é composta de União, Estados e Distrito Federal, e Municípios. Entidades que podem atuar em conjunto, preservandose a autonomia política, administrativa e financeira.

Os Municípios, nesta estrutura federativa, têm papel de destaque, pois são vistos como os que melhor podem atender às demandas da população, por estarem mais próximos de seus problemas e, supostamente, de suas soluções.

A administração pública municipal é a atividade pela qual busca-se satisfazer as demandas de interesse público local. Os gestores procuram interpretar e avaliar as necessidades e aspirações da sociedade, para atendê-las por intermédio dos serviços públicos. Entretanto, as administrações públicas municipais nos últimos anos vêm convivendo com ínúmeras mudanças de ordem financeira, estrutural e comportamental.

As mudanças de ordem financeira decorrem da escassez dos recursos necessários para custear os serviços públicos; as de ordem estrutural são devidas a fatores econômicos e sociais que pressionam os entes públicos municipais a expandirem os atendimentos à coletividade; as de natureza comportamental referem-se à forma de gerenciamento dos entes públicos e decorrem, principalmente, das imposições da Lei de Responsabilidade Fiscal (LRF). Com isso, o desafio maior que enfrentam os gestores é manter o atendimento às demandas da população por serviços públicos no quadro dessas alterações.

Matias-Pereira (2006, p. 305) afirma que "[ ...] com a Lei de Responsabilidade Fiscal foi deflagrado o processo para combater o crônico desequilíbrio fiscal da administração pública brasileira, tanto em nível federal, estadual, como municipal; por meio de um rígido controle do endividamento público [ ...]." A Lei de Responsabilidade Fiscal é um verdadeiro código de conduta para os administradores públicos na gestão das finanças públicas de todas as esferas de governo. A mencionada lei visa melhorar a administração das contas públicas do Brasil (Matias-Pereira, 2007).

A LRF estabelece mecanismos norteadores capazes de proporcionar grandes avanços na política de planejamento brasileira, inserindo no seu texto o elo entre orçamento, a programação financeira e o fluxo de caixa, além de instrumento de acompanhamento, avaliação e ajuste do que foi planejado e orçado, evidenciando assim novas visões sobre como racionalizar os gastos públicos em nível de União, Estados e Municípios (Santana, Pessoa, Cabra, Santos \& Diniz, 2007). Para os pequenos municípios a LRF se reveste de especial importância porque são estes os que contam com menor competência técnica nos seus quadros de funcionários, estão sujeitos a menor nível de despesa por munícipe e apresentam população de nível de renda mais baixo.

Em consonância com o que preconiza a LRF as administrações públicas, de todas as esferas, buscam implementar novas formas de administrar, saindo do enfoque exclusivamente legalista e passando a emprestar maior importância aos resultados. (Osborne \& Gaebler, 1995); (Bresser-Pereira, 1998); (MatiasPereira, 2007).

A inexistência de déficits orçamentários é considerada a situação ideal segundo os preceitos da LRF. Porém, nem sempre o cumprimento dessas diretrizes é possível, pois em função das inúmeras demandas sociais, o setor público vê-se simplesmente obrigado a realizar certos gastos e torna-se muito difícil evitar que sejam gerados déficits orçamentários (Luque \& Silva, 2004).

A busca pelo enfoque gerencial, voltada aos resultados, obviamente se faz no quadro das restrições legais a que está sujeito o gestor público. Então, diante da relevância que os municípios apresentam na estrutura político-administrativa brasileira, o espaço de manobra do gestor para decidir sobre a aplicação dos recursos se torna fundamental. Entende-se que o espaço de manobra é constituído pelo montante de recursos financeiros sobre os quais os gestores públicos efetivamente podem exercer escolha quanto à aplicação e é, portanto, o que permite aos municípios imprimir características próprias e diferenciadas às suas administrações.

Adota-se o pressuposto de que a LRF trouxe condicionamentos novos à gestão financeira no setor público e de que isso causou alteração no espaço de manobra à disposição dos gestores municipais. Tendo em vista esses pressupostos o presente artigo visa responder a seguinte questão: A LRF causou alteração no espaço de manobra da gestão financeira dos municípios pequenos e extremamente pequenos do Estado do Paraná? 
O objetivo geral é mensurar e avaliar os reflexos da LRF sobre o espaço de manobra da gestão financeira dos municípios paranaenses pequenos (com população entre 10 e 20 mil habitantes) e extremamente pequenos (com população menor que 5 mil habitantes). Para tanto, é necessário estabelecer e mensurar o constructo de espaço de manobra; analisar o impacto da LRF sobre o espaço de manobra; e identificar dentre as variáveis representativas de aspectos financeiros e de gestão, quais explicam melhor a mudança observada.

O presente artigo é composto de cinco seções. Após esta introdução, aborda-se a fundamentação teórica. Em seguida, apresenta-se a metodologia utilizada. Na quarta seção, são apresentados os resultados da pesquisa empírica e, por fim, a conclusão.

\section{Fundamentação Teórica}

Os fundamentos teóricos apresentados a seguir se referem à administração pública municipal, às finanças públicas; à gestão financeira municipal e a Lei de Responsabilidade Fiscal.

\subsection{Administração Pública}

Matias-Pereira (2008, p. 60) conceitua administração pública como “[...] o conjunto de serviços e entidades incumbidos de concretizar as atividades administrativas, ou seja, da execução das decisões políticas e legislativas". O autor define que o propósito da administração pública é "[ ...] a gestão de bens e interesses qualificados da comunidade no âmbito dos três níveis de governo: federal, estadual ou municipal, [ ...]".

Os objetivos dos Entes Públicos (Federal, Estaduais e Municipais) são atender às necessidades da população, que são crescentes, mediante a administração dos recursos públicos. Para Bobbio (1998 apud Matias-Pereira, 2008, p. 61) a administração pública “[ ...] designa o conjunto das atividades diretamente destinadas à execução das tarefas ou incumbências consideradas de interesse público ou comum, numa coletividade ou numa organização estatal".

Para Meirelles (2003, p. 63), o Governo é responsável pela condução dos negócios públicos, utilizando os Poderes e órgãos que o integram para atingir seus objetivos. O autor afirma, também, que "A Administração é o instrumental de que dispõem o Estado para pôr em prática suas opções de Governo." (Meirelles, 2003, p. 64). O Estado, que tem a responsabilidade de atender às demandas da sociedade, com serviços públicos de qualidade, os realiza por meio da administração pública.

\subsection{O município e o pacto federativo}

O Município, como unidade político-administrativa, surgiu com a República Romana, interessada em manter a dominação pacífica sobre as cidades conquistadas. Os vencidos ficavam sujeitos, desde a anexação ao império, às imposições do senado, mas, em troca da fiel obediência às leis romanas, a República concedia-lhes certas prerrogativas, que variavam de simples direitos privados até ao privilégio político de eleger seus governantes e dirigir a própria cidade (Meirelles, 2003, p. 31-32).

Segundo Slomski (2006), os municípios, no Brasil, existem desde o período colonial e tiveram na Constituição de 1988 seu ápice no que diz respeito à autonomia.

Destaca-se a autonomia municipal quanto:

a) a organização dos municípios, realizada por meio das Leis Orgânicas Municipais, com a observância dos limites impostos pela Constituição Federal;

b) ao processo eleitoral, baseada na eleição de Prefeitos e Vereadores em sufrágio universal, dentro das normas estabelecidas no direito eleitoral brasileiro; bem como, a definição das situações que podem resultar na cassação do mandato de agentes políticos e os procedimentos que dvem ser adotadas nessas situações;

c) a instituição, arrecadação e aplicação dos recursos decorrentes dos tributos de sua competência; 
d) a elaboração e execução do planejamento financeiro e orçamentários municipal por intermédio do Plano Plurianual (PPA), Lei de Diretrizes Orçamentárias (LDO) e da Lei Orçamentária Anual (LOA), observando as normas comuns a todos os entes públicos;

e) a definição das estruturas administrativas municipais envolvendo: regime jurídico dos servidores; planos de cargos, salários e carreiras; regime previdenciário; estrutura organizacional (organograma) entre outros.

Os municípios não podem sofrer quaisquer controles ou interferência dos outros entes da Federação nas matérias da sua competência, exceto nos casos de intervenção previstos na Constituição Federal.

Para Menezes (2002), o município é reconhecido como a instituição que pode levar de forma mais eficiente e eficaz a presença do poder público ao interior do País, além de poder desempenhar o papel de agente do desenvolvimento econômico local.

Matias e Campello (2000) corroboram esse entendimento afirmando que é no município, a menor unidade administrativa da Federação, onde se apresentam as condições mais adequadas para que seja formado um quadro nacional democrático e onde são geradas as situações mais favoráveis para intervenção, pelo fato de poder público local por estar mais próximo dos problemas e ser suscetível ao controle mais direto da sociedade.

A Constituição Federal de 1988 estabeleceu o Pacto Federativo vigente, que redefiniu a distribuição de recursos tributários entre os entes federados e instituiu a repartição de competências entre as unidades que compõem a Federação, definindo direitos e obrigações, próprias e concorrentes.

O Pacto Federativo estabelece a repartição das receitas tributárias entre os entes federados, no caso dos municípios, existe a garantia constitucional de participação nas receitas arrecadas sob a forma de tributos na União e do Estado em que faz parte, sendo os principais o Fundo de Participação dos Municípios - FPM (formado pela arrecadação federal do Imposto de Renda - IR e o Imposto sobre Produtos Industrializados - IPI) e o Fundo de Participação do ICMS (referente ao Imposto sobre Circulação de Mercadorias e Serviços arrecadado pelos Estados).

A distribuição dos tributos federais e estaduais não se apresenta uniforme diante dos critérios usados para a sua repartição. Enquanto o FPM utiliza o número de habitantes como metodologia para repartir o produto arrecadado; na divisão do ICMS cada Estado estabelece o seu critério de distribuição aos municípios. No caso dos tributos estaduais, outro fator a ser considerado é a industrialização e/ou nível desenvolvimento do Estado, que impacta fortemente em seu montante arrecadado e, consequentemente, nas receitas municipais.

Em relação a arrecadação da União, observa-se a prática de substituir os impostos por contribuições econômicas e de intervenção (PIS, COFINS, CSLL, CIDE). Isso porque, no caso das contribuições não existe a necessidade de partilha com os outros entes federados, com exceção da Contribuição de Intervenção do Domínio Econômico sobre os combustíveis (CIDE); o que caracteriza uma distorção do pacto federativo, pois, praticamente toda a arrecadação das contribuições permanece com a União.

Com isso, torne-se evidente que a equivalência econômico-financeira buscada pelo pacto federativo apresenta distorções, causando impacto sobre a gestão e as finanças públicas municipais, principalmente nos municípios de menor porte, dependentes, quase que exclusivamente, das transferências constitucionais. Neste contexto os gestores municipais precisam buscar formas de melhorar a utilização dos recursos financeiros disponíveis, bem como, distinguir os fatores que exercem influências sobre a administração financeira municipal.

\subsection{Gestão e finanças públicas municipal}

A gestão pública envolve a interpretação de objetivos a fim de transformá-los em ações organizacionais por meio do planejamento, da organização, da direção e do controle, devendo ser entendida como o conjunto de idéias, atitudes, normas e processos que determinam a forma de distribuir e de exercer a autoridade política e como se atendem aos interesses públicos (Matias-Pereira, 2007, p. 5).

Para Silva (2004, p. 179), a gestão pública está relacionada com “[...] os processos que visam à obtenção, transformação, circulação, aplicação e consumo de bens com o fito de atingir a finalidade proposta pela administração". 
A função da gestão pública é disponibilizar os serviços necessários à população, mediante a execução orçamentária. Em relação aos municípios, a gestão está associada às questões de interesse local e abrange aspectos orçamentários, financeiros e patrimoniais.

As melhorias da gestão pública, nos seus aspectos financeiros, econômicos, sociais e administrativos dependem da correta e persistente administração dos recursos financeiros, porque no ambiente público municipal, como de resto em todo o setor público, tais melhorias estão ligadas às receitas e às despesas, ou seja, revelam-se como relações basicamente financeiras.

Para D’Auria (1962, p. 63) as finanças públicas “[ ...], em sua vasta e ilimitada atuação, enfrentam e resolvem os problemas de natureza econômica que se desencadeiam da função de governo, donde se conclui que a função financeira se enquadra na ordem política e econômica do Estado". Segundo Matias e Campello (2000, p. 40) "[ ...] finanças públicas refere-se ao conjunto de problemas relacionados ao processo de Receitas-Despesas Governamentais e dos fluxos monetários".

Os Entes Públicos possuem a responsabilidade de viabilizar o funcionamento dos serviços públicos essenciais demandados pela coletividade. Para atingir ess objetivo necessitam de recursos financeiros, que são obtidos por meio de várias fontes, a fim de promover os serviços indispensáveis ao funcionamento das atividades estatais e ao bem comum da população. O custeio das necessidades públicas realiza-se por meio da transferência de parcelas dos recursos dos indivíduos e das empresas para os governos, completando assim o círculo financeiro entre sociedade e Estado (Matias-Pereira, 2006, p. 133-134). Esta relação é a principal preocupação das finanças públicas.

Segundo Matias-Pereira (2006), o objeto precípuo das finanças públicas é a atividade fiscal desempenhada com o propósito de obter e aplicar recursos para o custeio dos serviços disponibilizados aos cidadãos, sendo orientada segundo duas direções: 1) Política tributária: que se materializa na captação de recursos, para atendimento das funções da administração pública. 2) Política orçamentária: que se refere especificamente aos gatos, ou seja, aos atos e medidas relacionados com a forma da aplicação dos recursos, levando em consideração a dimensão e a natureza das atribuições do poder público, bem como a capacidade e a disposição para seu financiamento pela população.

No âmbito municipal, a gestão financeira refere-se aos procedimentos empregados na obtenção e administração dos recursos financeiros - receitas públicas - necessários para a realização dos serviços públicos e dos programas de interesse local, que constam no orçamento municipal e são executados ou desenvolvidos por intermédio das despesas públicas.

Os municípios, no desempenho de suas atividades e realização de seus fins, precisam obter meios financeiros, pela exploração de seu patrimônio, pelas contribuições representadas pelos tributos municipais e pela participação nas receitas do governo estadual e da União. Essa atividade que os municípios desenvolvem para atendimento das necessidades públicas é denominada por Silva (2004) de Gestão e Administração Financeira e consiste em obter, criar, gerir e despender os recursos financeiros indispensáveis àquelas necessidades.

A gestão financeira municipal preocupa-se com os recursos financeiros para o desenvolvimento das atividades inerentes a administração pública municipal, tanto no que tange as atividades-meio com as atividades-fins, que devem ser geridas pelo ente local. Na Figura 1 é apresentado o ciclo da gestão financeira municipal.

A gestão financeira municipal é baseada na relação receitas e despesas, as receitas são administradas com a finalidade de prover a realização dos serviços públicos municipais, que são efetivados por meio das despesas. Nos pequenos municípios as receitas têm origem tanto dentro do seu espaço geográfico, tributos municipais, como fora, mediante os direitos constitucionais de participar das receitas arrecadadas pela União e pelos Estados. Ressaltando, que nos pequenos municípios, essas participações representam a base de suas receitas.

O ciclo da gestão financeira municipal tem dois tipos de contribuinte os que estão dentro e os que estão fora do território municipal. Os municipais contribuem tanto, diretamente para as receitas dos municípios, por meio dos tributos, contribuições e serviços cobrados; quanto em conjunto com os demais contribuintes para as receitas da União e dos Estados, que são repassadas aos municípios na forma de transferências (constitucionais ou voluntárias) ou, ainda, na forma de empréstimos. Depois de arrecadadas as receitas são geridas pelos municípios e aplicadas nas despesas produzindo os serviços públicos, que são usufruídos pela população e pelos contribuintes municipais. 
Figura 1: Ciclo da gestão financeira municipal

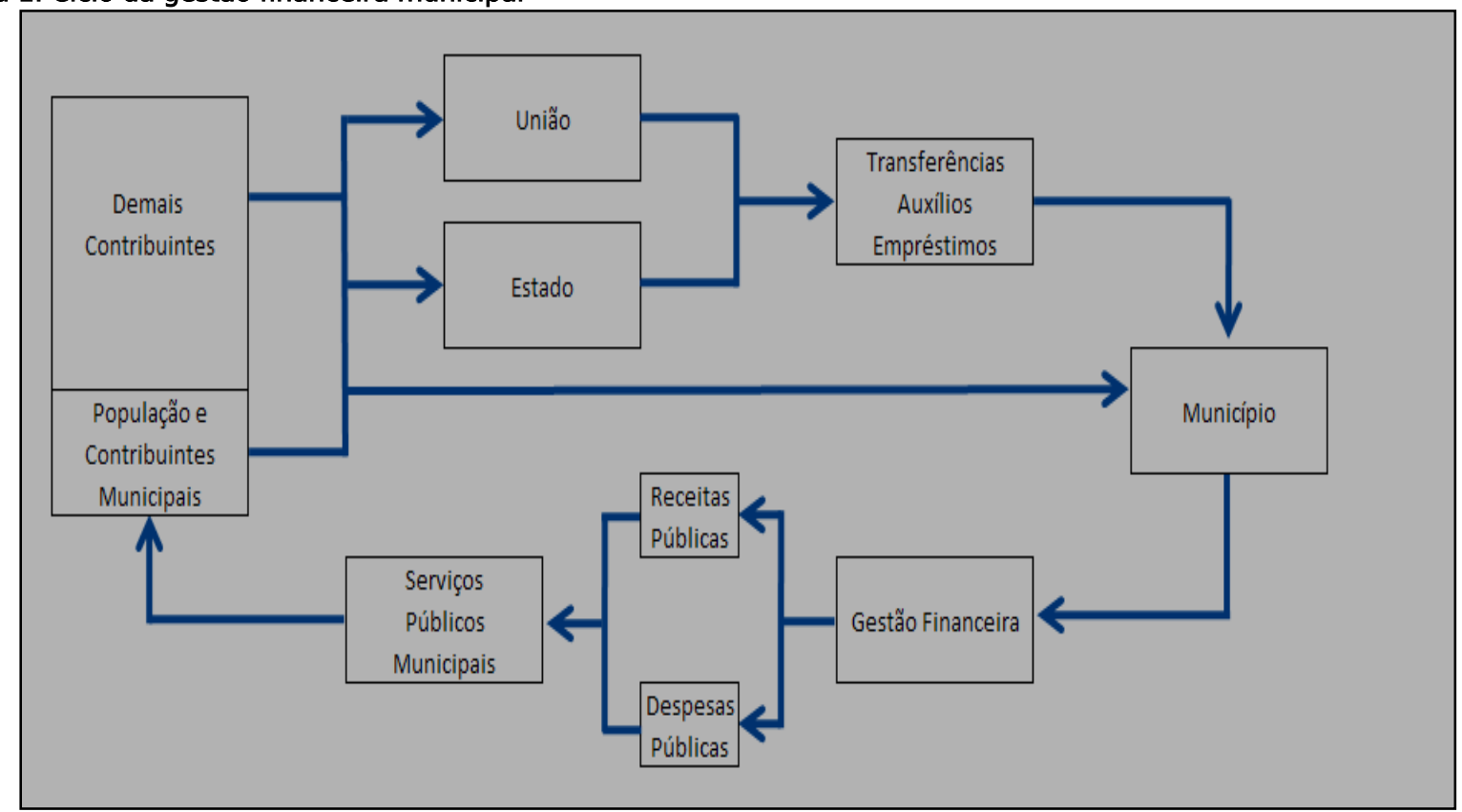

FONTE: Os autores (2010)

\subsection{Lei de Responsabilidade Fiscal (LRF)}

Em 4 de Maio de 2000, entrou em vigor a Lei Complementar $n^{\circ}$ 101, conhecida como Lei de Responsabilidade Fiscal (LRF), que estabeleceu às administrações públicas de todas as esferas o conceito de gestão fiscal responsável e que preconiza ação planejada e transparente; prevenção de riscos; equilíbrio das contas públicas; cumprimento de metas e de resultados; e cumprimento de vários limites, dentre os quais se destacam os limites de gastos com pessoal e com o montante do endividamento. Segundo Luque e Silva (2004), a LRF é fundamental, pois ressalta a noção básica de que a atuação apropriada do setor público no desempenho de suas funções supõe a obtenção de finanças coerentemente administradas.

A Lei de Responsabilidade Fiscal - LRF, segundo Nascimento e Debus (2002), Toledo Jr e Rossi (2005) e Nascimento (2006), incorpora alguns princípios e normas, decorrentes de experiências internacionais aplicadas na correção de problemas semelhantes aos enfrentados pelo setor público brasileiro, como:

a) Fundo Monetário Internacional - FMI - Fiscal Transparency,

b) Comunidade Econômica Européia - CEE - Tratado de Maastricht;

c) Nova Zelândia - Fiscal Responsibility Acy,

d) Estados Unidos da América - EUA - Budget Enforcement Act.

Para Nascimento e Debus (2002); Toledo Jr e Rossi (2005), as principais características das experiências internacionais são:

1) FMI - Fiscal Transparency: a) transparência dos atos que envolvam atividades fiscais passadas, presentes e programadas ou futuras; b) reforça o planejamento; c) informações orçamentárias apresentadas periodicamente aumentando a publicidade e a prestação de contas.

2) CEE - Tratado de Maastricht: a) critério para verificação da sustentabilidade financeira dos Estadosmembros; b) comprometimento dos membros com metas fiscais e com déficits fiscais excessivos; c) metas orçamentárias e para o endividamento, monitorados por uma comissão.

3) Nova Zelândia - Fiscal Responsibility Acy: a) o Executivo tem liberdade para orçar e gastar, porém, exige-se forte transparência sobre esses itens; b) redução das dívidas públicas a níveis prudentes; c) alcançar e manter níveis de patrimônio líquido para enfrentar possíveis riscos fiscais; d) gerenciamento dos riscos fiscais existentes.

4) EUA - Budget Enforcement Act. a) aplicado apenas ao Governo Federal; b) Congresso fixa metas de superávit e os mecanismos de controle seguem as regras do Budget Enforcement Act, c) 
Sequestration: limitação de empenho para garantir limites e metas orçamentárias; d) compensação orçamentária: atos que levem ao aumento das despesas devem ser compensados com redução de outras despesas ou aumento de receitas.

A responsabilidade na gestão fiscal induz na correta aplicação dos recursos disponíveis por parte das entidades públicas nos três níveis de governo, nos três Poderes e no Ministério Público, com senso de responsabilidade e fiel observância dos preceitos constitucionais e legais. O objetivo é prevenir os déficits nas contas públicas, manter sob controle o nível de endividamento público, impedindo que os gestores assumam obrigações e encargos sem a correspondente fonte de receita ou a redução da despesa, e impõe a imediata correção dos desvios na conduta fiscal, com a finalidade de assegurar o equilíbrio das finanças públicas.

A LRF, ao dispor sobre finanças públicas voltadas para a responsabilidade na gestão fiscal, tem como objetivos: melhorar a qualidade das ações de gestão fiscal dos recursos públicos confiados aos administradores públicos e coibir os abusos que provocam danos ou prejuízos ao patrimônio público (Matias-Pereira, 2006, p. 303).

Segundo Silva (2004), a LRF está apoiada em quatro eixos: o planejamento, a transparência, o controle e a responsabilização, que, em seu conjunto, são orientadores para a implantação do modelo de informações gerenciais, pois o planejamento e o controle são instrumentos fundamentais para a geração de informações úteis para auxiliar o processo decisório e conseqüentemente melhorar os demais eixos: a transparência e a responsabilização.

Para avaliar os objetivos da LRF e as mudanças proporcionadas no ambiente público, diversas pesquisas vêm sendo realizadas no Brasil.

Giuberti (2005) analisou o contexto fiscal dos municípios brasileiros e se a situação apresentada requeria controle de legislação específica. A pesquisa revela que a Lei de Responsabilidade Fiscal não proporcionou efeito sobre o comportamento dos gestores públicos em relação aos gastos com pessoal, pois poucos estavam acima do limite imposto. No entanto a LRF ocasionou impacto positivo sobre os Municípios que apresentavam um gasto elevado com esse tipo de despesa.

O estudo de Fioravante, Pinheiro e Vieira (2006) destaca que os municípios que gastavam uma pequena parcela da sua receita corrente líquida com pessoal aumentaram os seus gastos. Situação inversa ocorreu com os municípios que apresentavam gastos elevados de pessoal. De acordo com os pesquisadores houve um erro na definição do limite máximo para os gastos com pessoal, devido a não observância de que Estados e Municípios brasileiros são heterogêneos. Entretanto, quanto ao endividamento público, houve aumento crescente da dívida consolidada líquida nos governos locais. O estudo analisou 5.212 municípios em relação aos limites máximos impostos pela LRF e normas decorrentes de sua vigência.

Meneses (2006) pesquisou os municípios brasileiros e concluiu que as despesas com pessoal não foram afetadas pela LRF, assim como as outras despesas correntes. Constatou-se ainda, redução de investimentos (gastos em infra-estrutura) e aumento de despesas em função social. Por meio da análise de histograma, foi concluído também, que os municípios que estavam acima do limite de gastos com pessoal diminuíram suas despesas com funcionalismo, enquanto parte dos municípios que gastavam abaixo do limite imposto pela Lei aumentaram seus gastos relativos. O limite imposto pela LRF revelou-se, portanto, ineficaz, ao não considerar as características heterogêneas dos municípios.

Ao pesquisar as mudanças provocadas pela LRF no Rio Grande do Sul Chieza (http://hdl.handle.net/10183/22630) constatou que referida Lei contribuiu para reduzir o gasto com pessoal em relação a receita corrente líquida em todos os municípios pesquisados. De acordo com a pesquisa as exigências do equilíbrio fiscal impactaram de forma negativa nas despesas de capital e de forma positiva no superávit dos municípios.

Gapinski, Clemente, Taffarel e Gerigk (2010) pesquisaram se ocorreram alterações significativas nos indicadores de desempenho financeiro dos municípios com população entre 50 e 100 mil habitantes localizados no Sul do Brasil, entre a primeira gestão (período de 2001 a 2004) e a segunda gestão (período de 2000 a 2008) após a vigência da LRF. Os resultados da pesquisa indicaram que a LRF influenciou positivamente nas finanças dos municípios pesquisados por meio do aumento da capacidade de liquidez, redução em nível médio dos gastos com pessoal e endividamento, além de diminuir os restos a pagar entre as duas gestões analisadas. 
Como se observa se por um lado a LRF busca essencialmente o equilíbrio fiscal na gestão pública, os limites impostos pela referida Lei não considera as características heterogêneas dos municípios. Percebe-se que diversas pesquisas realizadas versam sobre o comportamento das finanças municipais em relação aos limites impostos pela nova legislação fiscal, mas, ainda, não são nítidos os efeitos dessas imposições sobre a administração financeira municipal, principalmente nos municípios menores, que dependem, quase que, exclusivamente de transferências constitucionais. Neste sentido, a presente pesquisa busca avaliar os reflexos da LRF sobre a gestão financeira dos municípios paranaenses com menos de 5 mil habitantes, denominados extremamente pequenos; e dos municípios paranaenses com população entre 10 e 20 mil habitantes, denominados pequenos; identificando quais fatores influenciam o espaço de gerenciamento financeiro à disposição dos gestores municipais, conforme metodologia apresentada e detalhada a seguir.

\section{Metodologia}

Quanto aos objetivos, a pesquisa desenvolvida se caracteriza como descritiva e explicativa, pois visa descrever o comportamento do espaço de manobra da gestão financeira municipal diante da vigência da LRF e explicar, por meio de variáveis financeiras e de gestão, o reflexo dessa lei sobre o espaço de gerenciamento financeiro dos municípios paranaenses extremamente pequenos e pequenos.

Os procedimentos utilizados compreendem pesquisa bibliográfica e documental. A pesquisa bibliográfica propiciou a fundamentação teórica. A pesquisa documental envolveu o levantamento de dados sobre as finanças dos municípios. Quanto à abordagem do problema, a pesquisa é caracterizada como quantitativa, com o emprego de análise estatística multivariada.

Neste artigo, busca-se, por meio da análise de regressão múltipla, relacionar o espaço de manobra da gestão financeira, variável dependente, com a vigência da LRF e outras variáveis observadas para os pequenos municípios paranaenses.

O modelo estatístico da regressão linear múltipla, segundo Cunha e Coelho (in Corrar, Paulo e Dias Filho, 2007, p. 135) é caracterizado na equação 1 :

$$
Y=\beta_{0}+\beta_{1} x_{1}+\beta_{2} x_{2}+\ldots+\beta_{n} x_{n}+\varepsilon
$$

Onde:

Yé a variável dependente

$X_{1}, X_{2} \ldots X_{n}$ são as variáveis independentes

$\boldsymbol{\beta}_{0}, \boldsymbol{\beta}_{1}, \boldsymbol{\beta}_{2} \ldots \boldsymbol{\beta}_{\mathrm{n}}$ são parâmetros da regressão

$\varepsilon$ é o resíduo ou erro da regressão

O objetivo da regressão linear múltipla é determinar as variáveis independentes que melhor explicam a variação da dependente e sua importância relativa, bem como, determinar a proporção explicada de tal variação.

A população compreende os municípios paranaenses com população até 5 mil habitantes (extremamente pequenos) e os com população entre 10 e 20 mil habitantes (pequenos), que disponibilizaram informações para os exercícios de 1998 e 2006 junto à Secretaria do Tesouro Nacional STN, conforme a Tabela 1.

A opção pelos exercícios de 1998 e 2006 visa evitar o período de adaptação à LRF. Em 1998, não se vislumbrava o advento da LRF, por isso este exercício se apresenta livre de seus efeitos. O ano de 2006 é bem posterior à entrada em vigor da Lei, no ano de 2000, e levando em consideração que o primeiro mandato municipal sob sua vigência foi encerrado em 2004, todas as adaptações já teriam ocorrido.

As variáveis independentes foram agrupadas em duas dimensões: financeira e de gestão. A dimensão financeira envolve as receitas e as despesas municipais; a dimensão de gestão abrange índices de liquidez, endividamento e forma de aplicação dos recursos financeiros municipais, como mostra a Figura 2. 
Tabela 1: População da pesquisa

\begin{tabular}{l|l|l|l|l|l|l|l}
\hline \multirow{2}{*}{ Municípios } & $\begin{array}{l}\text { Total } \\
\text { Municípios }\end{array}$ & \multicolumn{1}{l|}{$\begin{array}{l}\text { População da } \\
\text { pesquisa }\end{array}$} & $\begin{array}{l}\text { Total } \\
\text { Municípios }\end{array}$ & \multicolumn{2}{l}{$\begin{array}{l}\text { População } \\
\text { pesquisa }\end{array}$} \\
\cline { 2 - 8 } & Censo 2000 & 1998 & $\begin{array}{c}\text { \% do } \\
\text { Total }\end{array}$ & Censo 2007 & 2006 & $\begin{array}{l}\text { \% do } \\
\text { Total }\end{array}$ \\
\hline Com até 5 mil habitantes & 95 & 89 & 93,68 & 100 & 84 & 84,00 \\
\hline Entre 10 e 20 mil habitantes & 102 & 99 & 97,06 & 106 & 77 & 72,64 \\
\hline
\end{tabular}

Fonte: Os autores (2010)

Figura 2: Variáveis independentes das dimensões financeira e de gestão

\begin{tabular}{|c|c|c|c|}
\hline & VARI & VEIS & \\
\hline & FINANCEIRAS & & DE GESTÃO \\
\hline F1 & $\frac{\text { Receita Total }}{\text { Despesa Total }}$ & G1 & $\frac{\text { Ativo Financeiro }}{\text { Passivo Financeiro }}$ \\
\hline F2 & $\frac{\text { Passivo Permanente }}{\text { Receitas Correntes }}$ & G2 & $\begin{array}{l}\text { Ativo Financeiro + Ativo Permanente } \\
\text { Passivo Financeiro + Passivo Permanente }\end{array}$ \\
\hline F3 & $\frac{\text { Receita Tributária }}{\text { Receita Total }}$ & G3 & $\begin{array}{l}\text { Passivo Financeiro - Ativo Financeiro } \\
\text { Ativo Real }\end{array}$ \\
\hline F4 & $\frac{\text { Receitas Próprias }}{\text { Receita Total }}$ & G4 & $\begin{array}{l}\text { Despesas de Capital - Receitas de Capital } \\
\text { Receitas Correntes }\end{array}$ \\
\hline F5 & $\begin{array}{l}\text { Participação nas Receitas da União } \\
\text { Receita Total }\end{array}$ & G5 & $\frac{\text { Receitas Próprias }}{\text { Despesas Correntes }}$ \\
\hline F6 & $\begin{array}{l}\text { Participação nas Receitas do Estado } \\
\text { Receita Total }\end{array}$ & G6 & $\begin{array}{l}\text { Passivo Permanente } \\
\text { Ativo Real }\end{array}$ \\
\hline F7 & $\begin{array}{l}\text { Receita Líquida de Empréstimos = Operações } \\
\text { de Crédito -(Juros+Amortizações) } \\
\text { Receita Total }\end{array}$ & G7 & $\begin{array}{l}\text { Passivo Permanente } \\
\text { Ativo Financeiro }\end{array}$ \\
\hline F8 & $\frac{\text { Despesas com Pessoal }}{\text { Receitas Correntes }}$ & G8 & $\frac{\text { Superávit Corrente }}{\text { Receita Total }}$ \\
\hline F9 & $\frac{\text { Despesas com Juros }}{\text { Receitas Correntes }}$ & G9 & $\begin{array}{l}\text { Superávit Corrente } \\
\text { População }\end{array}$ \\
\hline F10 & $\begin{array}{l}\text { Despesas com Servicos de Terceiros } \\
\text { Receitas Correntes }\end{array}$ & G10 & $\frac{\text { Superávit Corrente }}{\text { Receitas Correntes }}$ \\
\hline F11 & $\begin{array}{l}\text { Outras Despesas Correntes } \\
\text { Receitas Correntes }\end{array}$ & G11 & $\frac{\text { Dívida Ativa }}{\text { Ativo Real }}$ \\
\hline
\end{tabular}

Fonte: Adaptado de Matias e Campello (2000); Kohama (2000); Andrade (2007)

A principal fonte de dados é a base Finanças do Brasil (FINBRA), da Secretaria do Tesouro Nacional (STN), mas também se recorreu ao Instituto Paranaense de Desenvolvimento Econômico e Social - IPARDES (Base de Dados do Paraná - BDE) e ao Portal de Controle Social do Tribunal de Contas do Estado do Paraná. Junto à FINBRA foram coletados os demonstrativos de receita, despesa, ativo e passivo dos municípios; do Portal de Controle Social, os dados de gastos dos Poderes Legislativos no exercício de 2006; e da BDE, os demais dados necessários.

Tendo em vista a periodicidade dos dados censitários de população, adotou-se para 1998 a população de 2000 e para 2006, a de 2007. As receitas próprias dos municípios foram obtidas pelo somatório das receitas: tributária, de contribuição, patrimonial, agropecuária, industrial, de serviços, outras receitas correntes e alienação de bens.

O modelo estimado pode ser expresso pela equação 2. A técnica de estimação utilizada foi a passo a passo (stepwise).

$$
E M=\alpha+\sum_{i=1}^{k} \beta_{i} X_{i}+\mu_{i}
$$

Onde:

EM - Espaço de manobra

$\boldsymbol{\alpha}$ - Constante

$\boldsymbol{X}_{\mathbf{i}}-$ Variáveis explanatórias

$\boldsymbol{u}_{\mathbf{i}}$ - Termo de disturbância 


\subsection{Constructo da pesquisa}

O espaço de manobra da gestão financeira municipal (EM) é definido e mensurado como segue.

Todas as decisões da administração pública são vinculadas ao aspecto legal, mas apesar disso, em algumas situações, o gestor público pode escolher em que, em que momento e de que forma realizar a aplicação de recursos. A Figura 3 apresenta os elementos de decisão do gestor público.

Figura 3: Elementos definidores do espaço de manobra da gestão financeira
\begin{tabular}{|l|l|}
\hline Item & Caracterização \\
\hline EM QUE APLICAR & $\begin{array}{l}\text { Vincula-se à destinação dos recursos financeiros: materiais, insumos, } \\
\text { serviços, contratação de terceiros, repasses a entidades, equipamentos, } \\
\text { construções. }\end{array}$ \\
\hline EM QUE MOMENTO APLICAR & Refere-se à distribuição dos desembolsos no tempo. \\
\hline DE QUE FORMA APLICAR & $\begin{array}{l}\text { Diz respeito à forma como serão empregados os recursos financeiros, se } \\
\text { de forma direta ou descentralizada. Tem estreita relação com a natureza } \\
\text { de despesa. }\end{array}$ \\
\hline
\end{tabular}

Fonte: Gerigk (2008)

O espaço de manobra da gestão financeira municipal (EM) é definido como a diferença entre o total das receitas correntes municipais e a soma das despesas com pessoal e encargos sociais, serviços das dívidas, despesas do Legislativo e as decorrentes das contribuições para o Programa de Formação do Patrimônio do Servidor Público (PASEP). O resultado alcançado representa o montante de recursos financeiros sobre o qual o administrador público pode exercer escolhas (Gerigk, 2008, p. 97).

O cálculo do espaço de manobra da gestão financeira municipal segue a fórmula:

\begin{tabular}{|l|}
\hline Total das Receitas Correntes \\
(-) Despesas com Pessoal e Encargos Sociais \\
(-) Despesas com Serviços das Dívidas \\
(-) Despesas com Legislativo Municipal \\
(-) Contribuição para o PASEP \\
= Espaço de Manobra da Gestão Financeira Municipal (EM)
\end{tabular}

As informações relativas a 1998 consolidam despesas do Poder Executivo e do Legislativo, porém as de 2006, somente para alguns municípios. Assim, para mensurar EM, tanto para o exercício de 1998 como para 2006, foram observados os seguintes procedimentos:

a. Em relação às despesas com pessoal de 1998, retirou-se do total das despesas consolidadas de pessoal o total informado como despesas com a Função Legislativa. Em 2006, usou-se o mesmo critério, porém, para os municípios que não apresentavam dados na FINBRA sobre o Legislativo, utilizou-se o Portal de Controle Social, do Tribunal de Contas do Estado do Paraná.

b. As despesas com juros e amortizações foram retiradas da base FINBRA da STN.

c. As despesas com o Legislativo em 1998 são as informadas na FINBRA. Para 2006, os dados foram retirados dos demonstrativos exigidos pela LRF e disponibilizados no Portal de Controle Social.

d. Os valores das despesas com o PASEP, tanto em 1998 como em 2006, foram calculados com base na Lei $n^{\circ}$ 9.715/98. Estabeleceu-se a base de cálculo com os dados das receitas informadas à FINBRA e mediante a aplicação da alíquota de $1 \%$, chegou-se ao valor.

EM foi também expresso como coeficiente em relação a receitas e despesas, como segue:

EM/RT - percentual do espaço de manobra em relação à receita.

EM/RC - percentual do espaço de manobra em relação às receitas correntes.

EM/DT - percentual do espaço de manobra em relação ao total das despesas.

EM/DC - percentual do espaço de manobra relação às despesas correntes. 


\subsection{Tratamento dos dados}

Os dados, após terem sido coletados e organizados, foram examinados com o objetivo de identificar possíveis valores atípicos (outliers). O resultado é mostrado na Figura 4.

Figura 4: Amostra da pesquisa

\begin{tabular}{|c|c|c|c|c|}
\hline \multirow{3}{*}{ Municípios pesquisados } & \multicolumn{4}{|c|}{ Municípios } \\
\hline & \multicolumn{2}{|c|}{$\begin{array}{l}\text { Até } 5 \text { mil } \\
\text { habitantes }\end{array}$} & \multicolumn{2}{|c|}{\begin{tabular}{|llll}
$\begin{array}{l}\text { Entre } 10 \\
\text { habitantes }\end{array}$ & & & \\
\end{tabular}} \\
\hline & \begin{tabular}{|l|l|} 
Exercício \\
de 1998 \\
\end{tabular} & \begin{tabular}{|l|} 
Exercício \\
de 2006 \\
\end{tabular} & \begin{tabular}{|l|} 
Exercício \\
de 1998 \\
\end{tabular} & $\begin{array}{l}\text { Exercício } \\
\text { de } 2006\end{array}$ \\
\hline \multirow{3}{*}{$\begin{array}{l}\text { Total inicial de observações } \\
\text { (-) Observações atípicas (outliers) } \\
\text { Total final de observações (municípios pesquisados) }\end{array}$} & 99 & 77 & 89 & 84 \\
\hline & (34) & $(18)$ & $(30)$ & (25) \\
\hline & 65 & 59 & 59 & 59 \\
\hline
\end{tabular}

Fonte: Os autores (2010)

Após, a retirada das observações atípicas passou-se à análise estatística com o objetivo de verificar o comportamento do espaço de manobra da gestão financeira municipal (EM) diante da vigência da Lei de Responsabilidade Fiscal.

\section{Apresentação e Análise dos Testes Multivariados}

Com a finalidade de verificar os reflexos da LRF sobre EM, os dados de 1998 e 2006, dos municípios paranaenses com população menor que 5 mil habitantes (extremamente pequenos), foram analisados em conjunto; mesmo procedimento empregado nos dados dos municípios paranaenses com população entre 10 e 20 mil habitantes (pequenos). Os cálculos foram realizados por meio da técnica estatística de regressão múltipla, usando o método stepwise, com nível de significância de 5\%.

\subsection{Análise de regressão dos municípios paranaenses extremamente pequenos - 1998 e 2006}

Uma vez que as variáveis independentes referem-se a coeficientes, é aconselhável, em princípio, que a variável dependente também o seja. A escolha do coeficiente de EM baseou-se na correlação de Pearson para o conjunto de observações dos dois exercícios, conforme mostra a Figura 5.

Figura 5: Matriz de correlação dos indicadores relativos ao espaço de manobra - 1998 e 2006 - municípios paranaenses extremamente pequenos

\begin{tabular}{|l|l|l|l|l|}
\hline Indicadores Relativos & EM/RC & EM/RT & EM/DT & EM/DC \\
\hline EM/RC & 1,000 & 0,892 & 0,578 & 0,862 \\
\hline EM/RT & 0,892 & 1,000 & 0,697 & 0,876 \\
\hline EM/DT & 0,578 & 0,697 & 1,000 & 0,724 \\
\hline EM/DC & 0,862 & 0,876 & 0,724 & 1,000 \\
\hline
\end{tabular}

FONTE: Os autores (2010).

O coeficiente de EM que apresenta associação mais forte com os demais é EM/DC - percentual do espaço de manobra em relação às despesas correntes.

O objetivo é avaliar se a entrada em vigor da LRF impactou o espaço de manobra da gestão financeira dos municípios paranaenses extremamente pequenos, e em que proporção isso teria ocorrido. Para tanto, foram agrupados os dados de 1998 e 2006 numa mesma base e identificadas às variáveis independentes mais relevantes pelo método stepwise. Incluiu-se uma variável dummy LRF com a seguinte representação: $1998=0$ e $2006=1$.

$$
\frac{E M}{D C}=1,055-1,182 F_{8}+0,652 G_{8}-0,073 F_{2}+0,233 F_{7}-0,944 F_{9}+0,005 G_{1} \quad R_{A J}^{2}=0,975
$$

Na Figura 6 são apresentados os valores de Tolerância e VIF, que evidenciam a ausência de multicolinearidade. O Gráfico 1 não mostra nenhum indício de heteroscedasticidade. 
Figura 6: Tolerância e VIF - 1998 e 2006

\begin{tabular}{|cc|c|c|}
\hline & Variáveis & Tolerância & VIF \\
\hline F8 & Despesas com Pessoal/Receitas Correntes & 0,7776 & 1,2859 \\
F8 & Superávit Corrente/Receita Total & 0,6132 & 1,6307 \\
F7 & Passivo Permanente/Receitas Correntes & 0,8837 & 1,1315 \\
F9 & Receita Líquida de Empréstimos/Receita Total & 0,8913 & 1,1219 \\
G1 & Despesas com Juros/Receitas Correntes & 0,8048 & 1,2424 \\
\hline
\end{tabular}

FONTE: Os autores (2010).

Os coeficientes estimados na análise de regressão e suas estatísticas dos municípios paranaenses extremamente pequenos são mostradas na Figura 7.

Figura 7: Tolerância e VIF - 1998 e 2006

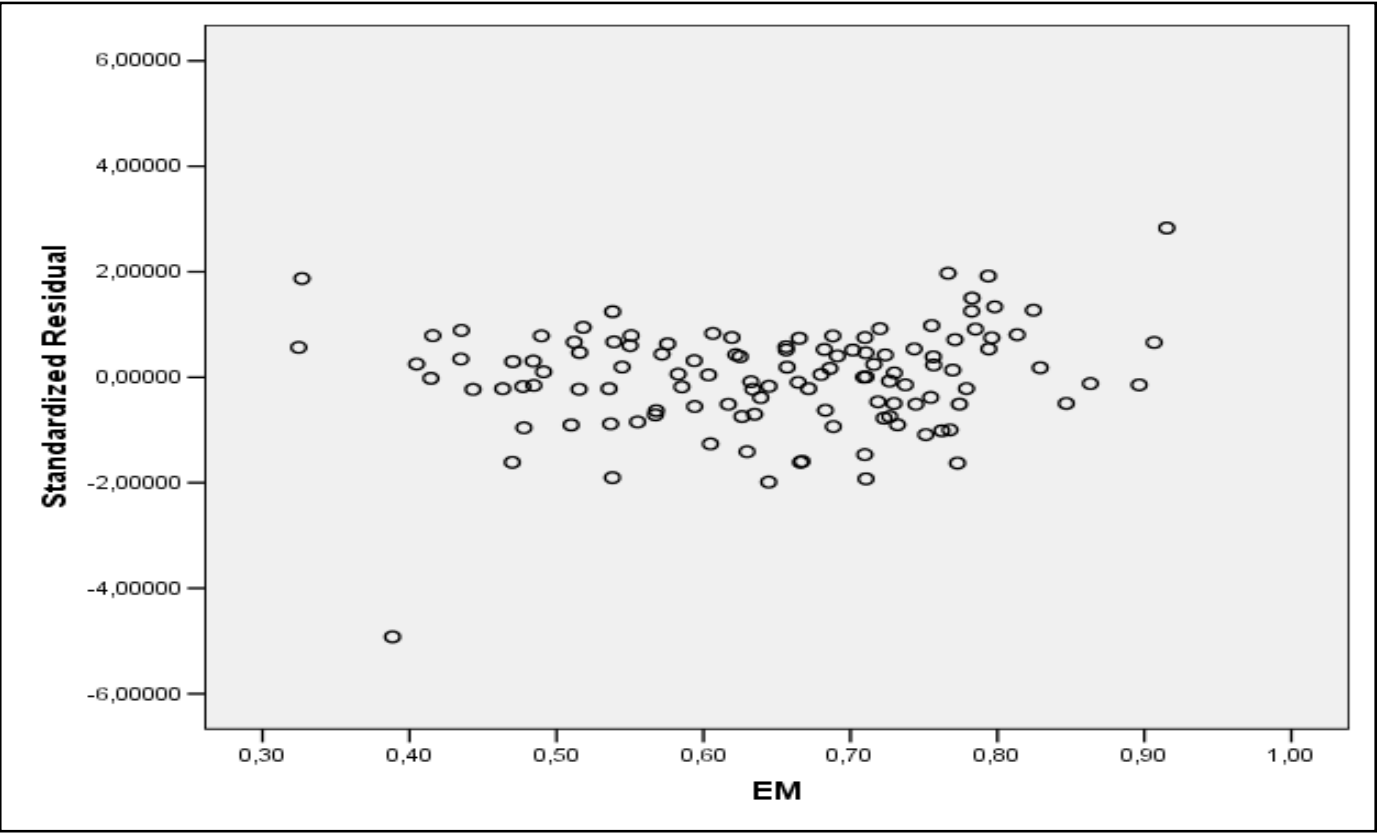

Fonte: Os autores (2010)

Figura 8: Coeficientes estimados e suas estatísticas - 1998 e 2006 - municípios paranaenses extremamente pequenos

\begin{tabular}{|l|l|l|l|l|}
\hline Variáveis & $\begin{array}{l}\text { Coeficiente } \\
\beta\end{array}$ & $\begin{array}{l}\text { Beta } \\
\text { Padronizado }\end{array}$ & $\begin{array}{l}\text { Estatística } \\
t\end{array}$ & Sig. \\
\hline Constante & 1,055 & & 75,04 & 0,000 \\
F8 Despesas com Pessoal/Receitas Correntes & $-1,182$ & $-0,637$ & $-38,51$ & 0,000 \\
G8 Superávit Corrente/Receita Total & 0,652 & 0,463 & 24,87 & 0,000 \\
F2 Passivo Permanente/Receitas Correntes & $-0,073$ & $-0,087$ & $-5,62$ & 0,000 \\
F7 Receita Líquida de Empréstimos/Receita Total & 0,233 & 0,067 & 4,36 & 0,000 \\
F9 Despesas com Juros/Receitas Correntes & $-0,944$ & $-0,051$ & $-3,18$ & 0,001 \\
G1 Ativo Financeiro/Passivo Financeiro & 0,005 & 0,035 & 2,27 & 0,025 \\
\hline
\end{tabular}

Fonte: Os autores (2010)

Diante dos valores dos betas padronizados, nota-se que as variáveis que mais contribuem para a explicação da dependente são: F8 - Despesas com Pessoal/Receitas Correntes (-0,637) e a G8 - Superávit Corrente/Receitas Totais $(0,463)$. A variável F8 é a mais influente sobre o EM, porém, diante da vigência da LRF a variável G8 apresenta-se com um valor significante em comparação com a F8 e, também, em relação às demais variáveis explicativas, inclusive sobre o efeito conjunto destas. Pode-se supor que diante da vigência da LRF os municípios paranaenses extremamente pequenos passaram a gerar superávits correntes mais significativos do que os conseguidos antes da vigência da nova lei, razão pela qual a variável G8 apresenta-se estatisticamente significante nas análises que envolveram os dois exercícios em conjunto. 
Na análise foi incluída a variável dummy LRF, para representar o exercício de 1998 e de 2006, antes e depois da vigência da Lei, entretanto, a referida variável não foi selecionada para compor a regressão, demonstrando, assim, que o advento da LRF não provou alterações no comportamento do espaço de manobra dos municípios paranaenses extremamente pequenos, evidenciando que o EM desses municípios não sofreu os efeitos restritivos da LRF, provavelmente, pelo fato de que já se encontrava restringido.

O sinal da variável F8 é negativo, indica que quanto maior forem as despesas com pessoal e encargos sociais, menor o montante de receitas correntes disponível e, conseqüentemente, menor o EM, desta forma, a variável contribui para diminuir o espaço de manobra.

A variável G8 mede a relação da poupança corrente com as receitas totais, com sinal positivo, expressa que quanto maior a poupança corrente maior será o espaço de manobra da gestão financeira municipal, contribuindo para aumentar o EM.

O sinal da variável F2 é negativo, com isso quanto maior for o montante do passivo permanente municipal menor será o EM, pois os pagamentos das despesas com amortizações serão custeadas pelas receitas correntes, assim a variável contribuiu na diminuição do EM.

Quanto a F7 seu sinal é positivo aumentando o espaço de manobra, desta forma, quanto maior for o montante de receitas obtidas maior o EM, pois, os novos investimentos são custeados por capitais de terceiros em vez das receitas correntes municipais.

A variável F9 apresenta sinal negativo que diminui o EM, assim, quanto maior as despesas com juros da dívida maior o consumo de receitas correntes, menor será o espaço de manobra.

A variável G1, com sinal positivo, contribui para aumentar o espaço de manobra, indica que quanto maior o ativo frente ao passivo municipal maior o valor do EM.

Por fim o intercepto da reta que apresenta sinal positivo, assim, assume-se que as demais variáveis independentes não selecionadas para a regressão não impactam, significativamente, sobre a variável dependente.

\subsection{Análise de regressão dos municípios paranaenses pequenos - 1998 e 2006}

A determinação da variável dependente, para a análise do espaço de manobra da gestão financeira nos municípios paranaenses pequenos, baseou-se na correlação de Pearson para o conjunto de observações dos dois exercícios e é apresentada na Figura 9.

Figura 9: Matriz de correlação dos indicadores relativos ao espaço de manobra - 1998 e 2006 - municípios paranaenses pequenos

\begin{tabular}{|l|l|l|l|l|}
\hline Indicadores Relativos & EM/RC & EM/RT & EM/DT & EM/DC \\
\hline EM/RC & 1,000 & 0,949 & 0,866 & 0,929 \\
\hline EM/RT & 0,949 & 1,000 & 0,936 & 0,936 \\
\hline EM/DT & 0,866 & 0,936 & 1,000 & 0,959 \\
\hline EM/DC & 0,929 & 0,936 & 0,959 & 1,000 \\
\hline
\end{tabular}

Fonte: Os autores (2010)

O coeficiente de EM que apresenta associação mais forte com os demais é EM/DC - percentual do espaço de manobra em relação às despesas correntes. Com o objetivo de avaliar se a LRF impactou o espaço de manobra da gestão financeira dos pequenos municípios paranaenses e em que extensão teria ocorrido; os dados de 1998 e 2006 foram agrupados numa mesma base; e incluiu-se uma variável dummy LRF representando: $1998=0$ e $2006=1$. A equação estimada é:

$$
\frac{E M}{D C}=-0,093+1,866 G_{8}+1,171 F_{11}+0,426 F_{7}-0,049 F_{2}-0,016 \text { Dummy }_{L R F}-0,108 F_{10} \quad R_{A J}^{2}=0,963
$$

Na Figura 10 são apresentados os valores de Tolerância e VIF, que evidenciam a ausência de multicolinearidade. A Figura 11, dos resíduos padronizados, não mostra nenhum indício de heteroscedasticidade. 
Figura 10: Tolerância e VIF - 1998 e 2006

\begin{tabular}{|ll|l|l|}
\hline Variáveis & & Tolerância & VIF \\
\hline G8 & Superávit Corrente/Receita Total & 0,4428 & 2,257 \\
F11 & Outras Despesas Correntes/Receita Correntes & 0,6414 & 1,559 \\
F7 & Receita Líquida de Empréstimos/Receita Total & 0,8769 & 1,140 \\
F2 & Passivo Permanente /Receitas Correntes & 0,8276 & 1,208 \\
LRF & Dummy antes e depois da LRF & 0,4218 & 2,370 \\
F10 & Despesas com Serviços Terceiros/Receitas Correntes & 0,7121 & 1,404 \\
\hline
\end{tabular}

Fonte: Os autores (2010)

Figura 11: Resíduos padronizados - 1998 e 2006

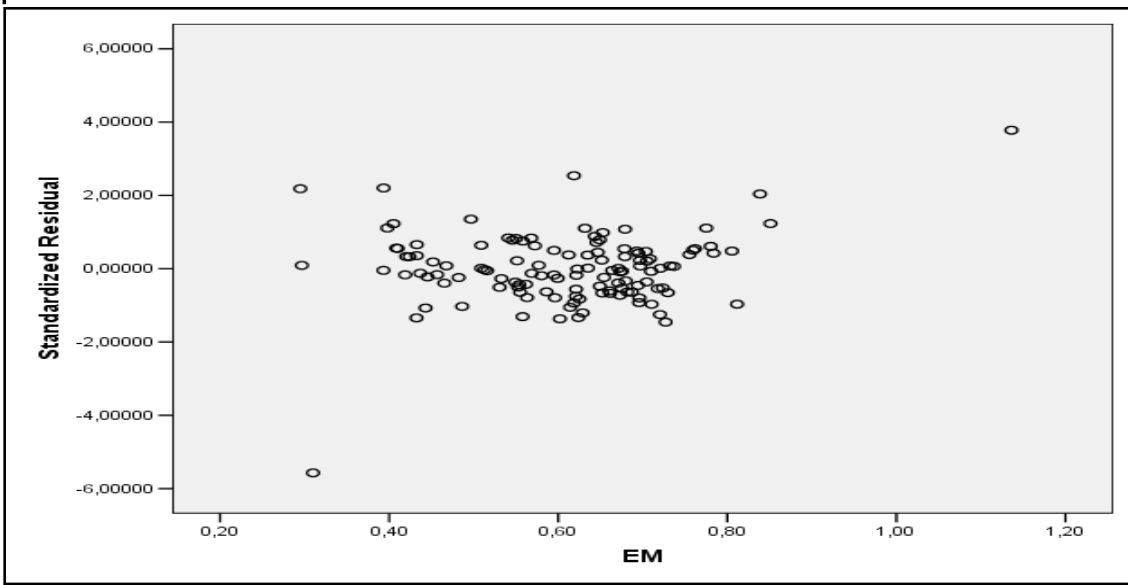

Fonte: Os autores (2010)

A Figura 12 apresenta os coeficientes estimados e suas estatísticas dos municípios paranaenses com população entre 10 e 20 mil habitantes.

Conforme os valores dos betas padronizados constantes da Figura 12, as variáveis independentes mais importantes na regressão, para os pequenos municípios, quando analisados os exercícios de 1998 e 2006 em conjunto, são: G8 - Superávit Corrente/Receita Total $(1,068)$ e F11 - Outras Despesas Correntes/Receitas Correntes (0,661).

Figura 12: Coeficientes estimados e suas estatísticas - 1998 e 2006 - municípios paranaenses pequenos

\begin{tabular}{|l|l|l|l|l|l|}
\hline Variáveis & $\begin{array}{l}\text { Coeficiente } \\
\beta\end{array}$ & $\begin{array}{l}\text { Beta } \\
\text { Padronizado }\end{array}$ & $\begin{array}{l}\text { Estatística } \\
t\end{array}$ & Sig. \\
\hline Constante & $-0,093$ & & $-5,69$ & 0,000 \\
G8 Superávit Corrente/Receita Total & 1,866 & 1,068 & 45,84 & 0,000 \\
F11 Outras Despesas Correntes/Receita Correntes & 1,171 & 0,661 & 34,15 & 0,000 \\
F7 Receita Líquida de Empréstimos/Receita Total & 0,426 & 0,099 & 6,01 & 0,000 \\
F2 Passivo Permanente/Receitas Correntes & $-0,049$ & $-0,086$ & $-5,05$ & 0,000 \\
LRF Dummyantes e depois da LRF & $-0,016$ & $-0,063$ & $-2,63$ & 0,009 \\
F10 Despesas com Serviços Terceiros/Receitas & $-0,108$ & $-0,042$ & $-2,26$ & 0,025 \\
\hline
\end{tabular}

Fonte: Os autores (2010)

A variável G8 mede a relação da poupança corrente com as receitas totais, com sinal positivo, expressa que quanto maior a poupança corrente maior será o espaço de manobra da gestão financeira municipal, contribuindo para aumentar o EM.

Quanto à variável F11, que estabelece a relação entre as outras despesas correntes e sua fonte de custeio, apresentou sinal positivo, assim, a variável provoca efeitos que aumentam o espaço de manobra.

Quanto a F7 seu sinal é positivo aumentando o espaço de manobra. Desta forma, quanto maior for o montante de receitas obtidas maior o EM, pois, os novos investimentos são custeados por capitais de terceiros em vez das receitas correntes municipais. 
O sinal da variável F2 é negativo, com isso quanto maior for o montante do passivo permanente municipal menor será o EM, pois os pagamentos das despesas com amortizações serão custeadas pelas receitas correntes, assim a variável contribuiu na diminuição do EM.

A LRF = Dummy antes e após a LRF, apresenta sinal negativo, com isso assume-se que a vigência da LRF produziu impacto negativo sobre o EM existente, contribuindo para sua diminuição.

A variável F10, com sinal negativo, evidencia que quanto maior as despesas com a contratação de mãode-obra de terceiros menor o EM, diante do consumo das receitas correntes, com isso a variável diminui o espaço de manobra.

A constante apresenta sinal negativo, assim, assume-se que as demais variáveis não selecionadas para o modelo podem impactar sobre a variável dependente, porém, como seu valor apresenta-se relativamente baixo e a significância é diferente de zero $(0,038)$, com isso, pode-se assumir que as variáveis independentes selecionadas na regressão explicam de forma relevante a dependente.

\subsubsection{Análises complementares - pequenos municípios paranaenses}

A seguir são apresentadas análises complementares das receitas e despesas orçamentárias dos pequenos municípios paranaenses, com o objetivo de explicar o comportamento do espaço de manobra da gestão financeira (EM). A Tabela 2 contém análise vertical das receitas correntes, expressas como soma das despesas e de EM, abrangendo os exercícios de 1998 e 2006.

Observa-se pela Tabela 2 que as despesas com pessoal, principal item de despesa, passa a representar percentual menor das receitas correntes em 2006. Isso, também, ocorre com as despesas de serviços das dívidas. Os percentuais referentes às despesas com Legislativo e com o PASEP mantiveram-se quase inalterados de um exercício para outro. A representatividade das despesas correntes e das despesas totais em relação às receitas correntes diminuiu significativamente de 1998 para 2006. Como consequência, a representatividade relativa de EM aumentou no mesmo período. A representatividade do superávit corrente mais do que dobrou no mesmo intervalo de tempo, variação captada pela variável G8 - Superávit Corrente/Receita Total. A análise precedente evidencia expressivas mudanças estruturais nos gastos públicos dos pequenos municípios paranaenses.

Tabela 2 - Análise vertical - 1998 e 2006

\begin{tabular}{|c|c|c|c|c|}
\hline Itens analisados & 1998 & $\%$ & 2006 & $\%$ \\
\hline Receitas Correntes & $11.369 .120,10$ & 100 & $13.637 .292,84$ & 100 \\
\hline Despesas com Pessoal & $4.614 .527,55$ & 40,6 & $5.291 .918,05$ & 38,8 \\
\hline Despesas com Serviços das Dívidas & $440.988,51$ & 3,9 & $356.926,56$ & 2,6 \\
\hline Despesas com Legislativo & $415.210,58$ & 3,7 & $452.007,29$ & 3,3 \\
\hline Despesas com PASEP & $118.933,79$ & 1,0 & $139.673,97$ & 1,0 \\
\hline Espaço de Manobra & $5.779 .459,66$ & 50,8 & $7.396 .766,97$ & 54,2 \\
\hline Despesas Correntes & $10.564 .985,71$ & 92,9 & $11.177 .687,07$ & 82,0 \\
\hline Despesas Totais & $12.655 .993,46$ & 111,3 & $12.586 .711,48$ & 92,3 \\
\hline Outras Despesas Correntes & $5.829 .379,67$ & 51,3 & $5.818 .438,34$ & 42,6 \\
\hline Superávit Corrente & $804.134,39$ & 7,1 & $2.459 .605,77$ & 18,0 \\
\hline
\end{tabular}

Fonte: Os autores (2010)

Na Tabela 3 é apresentada análise horizontal de 1998 para 2006, envolvendo os mesmos elementos que compõem a análise vertical.

Pela Tabela 3, verifica-se que as receitas correntes cresceram 20\% entre 1998 e 2006 e que as despesas com pessoal, serviços das dívidas, despesas com o Legislativo e a contribuição para o PASEP tiveram crescimentos menores. Consequentemente, EM, mensurado em valores absolutos, cresceu $28 \%$ no período.

As análises complementares mostram claramente que o vigoroso crescimento do superávit corrente e, particularmente, de EM, entre 1998 e 2006, por um lado, e o crescimento moderado das despesas correntes no mesmo período, por outro, resultam na elevação significativa de EM/DC médios, que passam de $55,32 \%$ para $66,77 \%$. 
Tabela 3 - Análise horizontal - 1998 e 2006

\begin{tabular}{|c|c|c|c|c|}
\hline Itens analisados & 1998 & $\%$ & 2006 & $\%$ \\
\hline Receitas Correntes & $11.369 .120,10$ & 100 & $13.637 .292,84$ & 120,0 \\
\hline Despesas com Pessoal & $4.614 .527,55$ & 100 & $5.291 .918,05$ & 114,7 \\
\hline Despesas com Serviços das Dívidas & $440.988,51$ & 100 & $356.926,56$ & 80,9 \\
\hline Despesas com Legislativo & $415.210,58$ & 100 & $452.007,29$ & 108,9 \\
\hline Despesas com PASEP & $118.933,79$ & 100 & $139.673,97$ & 117,4 \\
\hline Espaço de Manobra & $5.779 .459,66$ & 100 & 7.396.766,97 & 128,0 \\
\hline Despesas Correntes & $10.564 .985,71$ & 100 & $11.177 .687,07$ & 105,8 \\
\hline Despesas Totais & $12.655 .993,46$ & 100 & $12.586 .711,48$ & 99,4 \\
\hline Outras Despesas Correntes & $5.829 .379,67$ & 100 & $5.818 .438,34$ & 99,8 \\
\hline Superávit Corrente & $804.134,39$ & 100 & $2.459 .605,77$ & 305,8 \\
\hline
\end{tabular}

Fonte: Os autores (2010)

A Figura 13 mostra os valores médios e a variabilidade de F11 - Outras Despesas Correntes/Receitas Correntes nos exercícios considerados.

Figura 13: Estatística descritiva da variável F11 - Outras despesas corrente/receitas corrente

\begin{tabular}{|l|l|l|}
\hline Estatística Descritiva Variável F11 & 1998 & 2006 \\
\hline Média & 49,24 & 40,45 \\
\hline Desvio-padrão & 8,45 & 5,02 \\
\hline Coeficiente de Variação & 17,16 & 12,43 \\
\hline
\end{tabular}

Fonte: Os autores (2010)

Essas mudanças estruturais no orçamento dos pequenos municípios paranaenses explicam o sinal aparentemente invertido da variável F11 - Outras Despesas Correntes/Receitas Correntes nas análises de regressão realizadas, pois, as despesas correntes, ao contrário das receitas correntes, diminuíram entre os exercícios de 1998 e 2006.

\section{Conclusões}

A complexidade da administração pública, e da gestão financeira pública, em particular, não permite inferir diretamente as mudanças profundas trazidas pela LRF e, dada a experiência brasileira, poderia mesmo haver dúvida sobre a efetividade da Lei.

As contingências a que estão sujeitos os gestores financeiros dos municípios, especialmente os dos municípios muito pequenos, com enorme dependência em relação às transferências dos governos estadual e federal, estariam a reforçar o questionamento quanto à efetividade da Lei.

A pesquisa teve por objetivo avaliar e mensurar os reflexos da LRF sobre o Espaço de Manobra da Gestão Financeira dos municípios paranaenses com menos de 5 mil habitantes, denominados extremamente pequenos; e dos municípios paranaenses com população entre 10 e 20 mil habitantes, denominados pequenos; por meio de variáveis representativas de aspectos financeiros e de gestão.

Com base na revisão teórica, estabeleceu-se o constructo de Espaço de Manobra da Gestão Financeira Municipal (EM), definiu-se sua forma de cálculo e fizeram-se as mensurações para os exercícios financeiros de 1998 e 2006, o primeiro representando situação isenta de efeitos da LRF e o segundo, situação em que seus efeitos já se encontravam plenamente desenvolvidos. O coeficiente de EM em relação às despesas correntes (EM/DC) constitui a variável dependente, cujos valores foram calculados para ambos os exercícios analisados.

Nas análises foram incluídas variáveis dummies LRF, para representar o exercício de 1998 e de 2006 , antes e depois da vigência da Lei Fiscal. Os resultados obtidos por meio das regressões multivariadas apresentam completa conformidade com os pressupostos dessa análise e os sinais dos coeficientes estimados se apresentam como esperado. As regressões efetuadas mostram coeficientes de determinação ajustados $\left(R^{2}\right.$ ajustado $)$ muito significativos, superiores a $95 \%$ e interceptos positivos. Com base nisso, pode-se 
afirmar que as variáveis independentes incluídas nas regressões explicam com robustez a variação do espaço de manobra da gestão financeira municipal.

Os resultados da pesquisa evidenciam que nos municípios extremamente pequenos o fator mais relevante para a gestão financeira está associado com as despesas com pessoal, representada pela variável F8 - Despesas com Pessoal/Receitas Correntes. Para que os gestores municipais possam maximizar o espaço de gerenciamento financeiro faz-se necessário manter e/ou aumentar a vigilância e o controle sobre as despesas com pessoal, pois quanto menores forem as despesas com a folha de pagamento e os encargos sociais maior o EM gerado.

Nos municípios pequenos fator mais impactante sobe o EM diz respeito a diferença entre as receitas e as despesas correntes, que representa a capacidade de poupança dos municípios, traduzida pela variável G8 - Superávit Corrente/Receita Total. Nesse grupo de municípios, diferente dos extremamente pequenos, o espaço de manobra financeiro não está diretamente vinculado aos gastos com funcionalismo público, mas sim ao controle sobre o conjunto de despesas necessárias à manutenção e realização dos serviços municipais.

Os resultados da pesquisa, também, revelam que o mais aconselhável para o aumento do espaço de manobra da gestão financeira municipal é conciliar a redução das despesas com pessoal com a das demais despesas utilizadas para manter os serviços públicos, dessa forma consome-se menos receitas correntes e aumenta-se o superávit corrente, contribuindo, assim para o incremento do EM.

As análises indicam que o advento da LRF não provocou alterações no comportamento do espaço de manobra dos municípios paranaenses extremamente pequenos, evidenciando que o EM desses municípios não sofreu os efeitos restritivos da LRF, provavelmente, pelo fato de que já se encontrava restringido; e quanto aos pequenos municípios paranaenses, a despeito das pressões e das restrições a que já se encontravam submetidos seus orçamentos, o espaço de manobra dos gestores desses municípios passou a depender mais fortemente da capacidade de pouparem receitas correntes.

A LRF provocou mudanças na estrutura de EM/DC dos pequenos municípios paranaenses, a variável G8 Superávit Corrente/Receita Total, não se mostra sensível à inclusão da dummy LRF na análise conjunta dos dois exercícios financeiros. Porém, a variável F11 - Outras Despesas Correntes/Receitas Correntes apresenta significativa elevação do coeficiente beta padronizado nas estimações realizadas para os anos de 1998 e 2006, e tal elevação, pode aproximadamente toda, ser atribuída às exigências impostas pela LRF de controle sobre os gastos públicos.

Os resultados obtidos permitem concluir que, nos pequenos municípios paranaenses, o advento da LRF tornou os gestores muito mais parcimoniosos na realização de despesas e contribuiu decisivamente para aumentar o espaço de manobra da gestão financeira municipal. Melhor planejamento e controle na gestão financeira das receitas e despesas municipais teriam feito emergir uma mudança estrutural, observada na composição do Espaço de Manobra (EM) e, portanto, no significado do EM/DC.

Como limitação da pesquisa, destaca-se que as análises envolveram os municípios paranaenses com menos de 5 mil habitantes e os com população entre 10 e 20 mil habitantes, nos exercícios de 1998 e 2006. Desta forma, os resultados encontrados são, em princípio, limitados a este universo. Deve-se, também, observar que as variáveis empregadas no estudo foram definidas com base em investigação bibliográfica, existindo, portanto, a possibilidade de variáveis relevantes não serem consideradas; bem como, a confiabilidade dos dados da FINBRA/STN.

Estudos semelhantes, envolvendo municípios de outros Estados ou regiões do País, quem sabe utilizando variáveis distintas possibilitariam comparações e generalizações mais seguras. Diante do comportamento apresentado pela variável representativa de superávit corrente, sugere-se verificar que fatores mais influenciam o superávit corrente municipal e como este vem sendo aplicado pelos gestores municipais.

\section{Referências}

Andrade, N. A. (2007). Contabilidade pública na gestão municipal (3a ed.). São Paulo: Atlas.

Brasil. Secretaria do Tesouro Nacional - Stn. Finbra - Finanças do Brasil. http://www.tesouro.fazenda.gov.br. 
Bresser Pereira, L. C. (1998). Gestão do setor público: estratégia e estrutura para um novo Estado. In: Bresser Pereira, L. C. e Spink, P. (Organização.). Reforma do estado e administração pública gerencial. São Paulo: FGV.

Chieza, R. A. (2008). O ajuste das finanças públicas municipais à Lei de Responsabilidade Fiscal: os municípios do RS. 200 f. Tese de Doutorado. (Doutorado em Economia do Desenvolvimento). Universidade federal do Rio Grande do Sul.

Cunha, J. V. A. e Coelho, A. C. (2007). Regressão linear múltipla. In: Corrar, L. J., Paulo, E. e Dias Filho, J. M. Análise multivariada: para os cursos de administração, ciências contábeis e economia. São Paulo: Atlas, pp.131-231.

D'Áuria, F. (1962). Ciência das finanças: teoria e prática (2a ed.). São Paulo: Companhia Editora Nacional. p. 63 .

Fioravante, D. G., Pinheiro, M. M. S. e Vieira, R. da S. (2006). Lei de responsabilidade fiscal e finanças públicas municipais: impactos sobre despesas com pessoal e endividamento. Brasília: Instituto de Pesquisa Econômica Aplicada - IPEA.

Gapinski, I., Clemente, A., Taffarel, M. e Gerigk, W. (2010). O impacto da LRF no desempenho financeiro dos municípios de médio porte do sul do Brasil. In: Anais do Congresso Internacional de Administração, Ponta Grossa, PR, Brasil, 22.

Gerigk, W. (2008). O impacto da Lei de Responsabilidade Fiscal sobre a gestão financeira dos pequenos municípios do Paraná. 2008. 315 f. Dissertação (Mestrado em Contabilidade). Curso de Pós-Graduação em Contabilidade, Universidade Federal do Paraná-UFPR, Curitiba. p. 97.

Giuberti, A. C. (2005). Efeitos da lei de responsabilidade fiscal sobre os gastos dos municípios brasileiros. 2005. 54 f. Dissertação (Mestrado em Economia). Curso de Pós-Graduação em Economia, Universidade de São Paulo - USP, São Paulo.

Ipardes - Instituto Paranaense de Desenvolvimento Econômico e Social. Apresenta informações sobre dados estatísticos do Estado do Paraná. http://www.ipardes.pr.gov.br.

Kohama, H. (2000). Balanços públicos: teoria e prática (2a ed.). São Paulo: Atlas.

Luque, C. A. e Silva, V. M. (2004). A lei de responsabilidade na gestão fiscal: combatendo falhas de governo à brasileira. Revista de Economia Política, 24 (3), jul-set.

Matias, A. B. e Campello, C. A. G. B (2000). Administração financeira municipal. São Paulo: Atlas. p. 40.

Matias-Pereira, J. (2006). Finanças públicas: a política orçamentária no Brasil (3a ed.). São Paulo: Atlas. pp. $133,134,303,305$.

(2007). Manual de gestão pública contemporânea. São Paulo: Atlas. p. 5.

(2008). Curso de administração pública: foco nas instituições e ações governamentais. São Paulo: Atlas. pp. 60, 61 .

Meirelles, H. L. (2003). Direito administrativo brasileiro (28a ed.). São Paulo: Malheiros Editores. pp. 31,32, 63,64 .

Meneses, R. T. de (2006). Efeitos da Lei de Responsabilidade Fiscal sobre as categorias e funções de despesas dos municípios brasileiros (1998 - 2004). 2006. 128 f. Dissertação (Mestrado em Economia). Curso de Pós-Graduação em Economia, Universidade de São Paulo - USP, São Paulo.

Menezes, A. M. F. (2002). O processo de descentralização e as contas públicas: um estudo sobre as bases financeiras municipais baianas. 2002. 188 f. Tese (Doutorado em Administração). Curso de pós-graduação em administração, Universidade Federal da Bahia, Salvador.

Nascimento, E. R. e Debus, I. (2002). Lei complementar no 101/2000: entendendo a lei de responsabilidade fiscal. Brasília: ESAF

Nascimento, E. R. (2006). Gestão pública. São Paulo: Saraiva.

Osborne, D. \& Gaebler, T. (1999). Reinventando o governo: como o espírito empreendedor está transformando o setor público (8a ed.). Brasília: MH Comunicações. 
Silva, L. M. (2004). Contabilidade governamental: um enfoque administrativo (7a ed.). São Paulo: Atlas. p. 179.

Slomski, V. (2006). Manual de contabilidade pública: um enfoque na contabilidade municipal, de acordo com a Lei de Responsabilidade Fiscal (2a ed.). São Paulo: Atlas.

Santana, E. W. F., Pessoa, L. G. S. B., Cabra, L. M. M. A. C., Santos, S. R. B. e Diniz, J. A. (2007). Eficácia orçamentária municipal: os impactos produzidos pela lei de responsabilidade fiscal. 2007. In: Anais do Encontro da Anpad, Rio de Janeiro, RJ, Brasil, 31.

Toledo Jr, F. C. e Rossi, S. C.(2005). Lei de responsabilidade fiscal: comentada artigo por artigo (3a ed.). São Paulo: NDJ. 